\title{
Detection and properties of plasmid-like DNA in isolates from nine anastomosis and intraspecific groups of Rhizoctonia solani
}

\author{
Atsushi Miyasaka, Chung L. Chen and Teruyoshi Hashiba* \\ Faculty of Agriculture, Tohoku University, 1-1 Tsutsumidori Amamiyamai, Sendai 981, Japan
}

(Received 9 March 1990; revised 21 May 1990; accepted 8 June 1990)

\begin{abstract}
Plasmid-like DNA (pIDNA) was found in 48 out of 114 field isolates of Rhizoctonia solani. These 48 isolates were distributed as follows among the nine anastomosis groups (AG) and intraspecific groups (ISG) recognized among Japanese isolates of $R$. solani: 0 in AG-1 (sasakii type), 1 in AG-1 (web-blight type), 0 in AG-2-1, 11 in AG-2-2 (rush type), 10 in AG-2-2 (root rot type), 10 in AG-3, 8 in AG-4, 4 in AG-5 and 4 in AG-6. Each isolate carried one, two or three pIDNAs identified by gel electrophoresis. Electron microscopic analysis revealed that all these pIDNAs were linear molecules. The sequence homology among plDNAs found in representative isolates was examined by Southern blot analysis, using nick-translated pIDNAs as probes. Considerable sequence homology was observed among pIDNAs obtained from isolates within the same AG and ISG. The pIDNAs occurring in the isolates of AG-2-2 were classified into two groups on the basis of the sequence homology.
\end{abstract}

\section{Introduction}

The phytopathogenic fungus Rhizoctonia solani Kühn causes damping off in some 200 plant species, and has a wide host range. Vegetative incompatibility in this fungus is determined by anastomosis (AG) and intraspecific (ISG) groups. Japanese isolates have been divided into 9 AGs and ISGs. Of these, AG-1, AG-2-1, AG-2-2, AG-3 and AG-4 correspond to sasakii type (IA) and webblight type (IB), winter crop type (II), rush type (IIIB) and root rot type (IV), potato type (IV), and praticola type (IIIA), respectively, based on pathogenicity to field crops and cultural behaviour (Watanabe \& Matsuda, 1966).

There have been various reports of the presence of plasmid-like DNAs (plDNAs) in phytopathogenic fungi (Garber et al., 1984; Giasson \& Lalonde, 1987; Hashiba et al., 1984; Honeyman \& Currier, 1986; Kim et al., 1988; Kistler \& Leong, 1986; Rubidge, 1986; Samac \& Leong, 1988; Tudzynski \& Esser, 1986). In each case the plDNAs were linear molecules. Most of the linear pIDNAs in phytopathogenic fungi have terminal proteins covalently attached to the $5^{\prime}$ termini (Kistler \& Leong, 1986). Recently, we showed that the pRS64 plasmids found in one isolate of AG-4 in $R$. solani have hairpin loops at both termini (Miyashita et al., 1990).

Abbreviations: AG, anastomosis group; ISG, intraspecific group; pIDNA, plasmid-like DNA.
Little is known about the function of these linear plDNAs in phytopathogenic fungi. The unique mitochondrial plasmids found in Fusarium oxysporum were correlated with different pathotypes that attack crucifers (Kistler \& Leong, 1986; Kistler et al., 1987) and the pRS64 plasmids were found in a weakly pathogenic isolate of $R$. solani (Hashiba et al., 1984; Hashiba, 1987a, b).

In this report we describe the properties of pIDNAs found in 48 isolates from nine AGs and ISGs of $R$. solani isolated from various plants and soils in Japan. A preliminary account of this work has appeared elsewhere (Hashiba, 1988; Miyasaka et al., 1988).

\section{Methods}

Fungal isolates. Fungal isolates used in the study (Table 1) were maintained on potato sucrose agar medium at ambient laboratory temperature. Cultures for DNA extraction were grown to the stationary phase at $28^{\circ} \mathrm{C}$ in a potato/sucrose liquid medium as described previously (Hashiba et al., 1984). After 1-2 weeks, mycelia were harvested, washed, frozen at $-70^{\circ} \mathrm{C}$, and lyophilized.

Detection and preparation of plDNA. plDNA was detected using a slight modification of the procedure of Hirt (1967). Ten grams of lyophilized mycelium was ground to powder and suspended in $160 \mathrm{ml}$ $0 \cdot 1 \mathrm{M}$-citrate/phosphate buffer ( $\mathrm{pH} \mathrm{6.0)}$ containing $0.1 \mathrm{M}$-EDTA and then lysed by adding $20 \mathrm{ml} \mathrm{10 \% (w/v)} \mathrm{SDS} \mathrm{solution.} \mathrm{After} \mathrm{the} \mathrm{addition}$ of $5 \mathrm{M}-\mathrm{NaCl}$ to a final concentration of $1 \mathrm{M}$, this mixture was kept on ice overnight and then centrifuged at $15000 \mathrm{~g}$ for $30 \mathrm{~min}$. The mixtures were precipitated with 0.6 volumes of 2-propanol at $0{ }^{\circ} \mathrm{C}$, and the precipitates were collected by centrifugation. The total DNA precipitated was resuspended in $7 \mathrm{ml}$ TE $(20 \mathrm{~mm}$-Tris, $0.25 \mathrm{~mm}-\mathrm{EDTA}$, $\mathrm{pH} 8.0$ ) buffer containing $0.4 \%$ Sarkosyl, and purified by $\mathrm{CsCl}$ density- 
Table 1. Detection of plDNA in total DNA of R. solani isolates studied

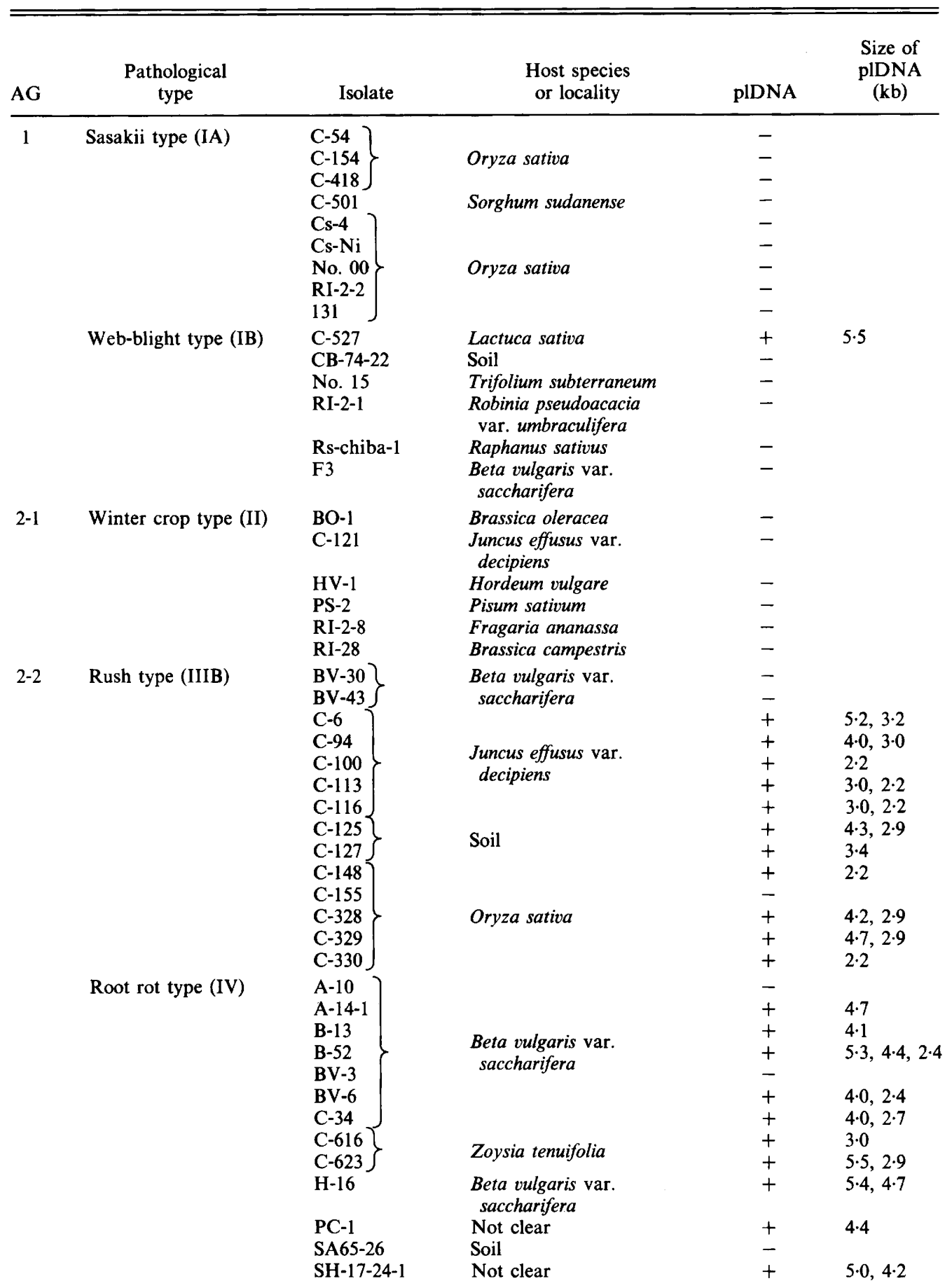


Potato type (IV)

4 Praticola type (IIIA)

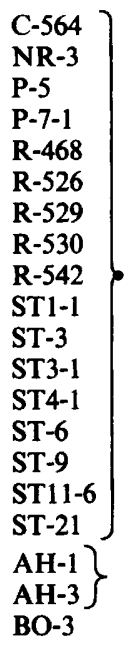

C-549

C-656

Chr-3

GM-7

GM-11 $\}$

HI521-21

L-1

P-10

R97

R101

$\mathrm{Rh}-131$

RI-64

SH-34

U-6

$1271 \mathrm{C}$

AL-1

C-672

GM-1

GM-10 $\}$

L-12

R-35

SD-521-18

SH-30

SH-31

ST2-1

ST6-1 $\}$

ST-8

W-3

WD-1

WD-23

501

Br-28

HAM-1-1

HI-5-11

HI-5-16

HN1-1

IS1-1

KNB2-2

NAT-3-1

NKN-2-1

OHT1-1

SH-13

Shi741

SO2-1

TSH1-1

UBU1-A
Solanum tuberosum

Arachis hypogaea

Brassica oleracea

(botrytis group)

Soil

Arachis hypogaea

Chrysanthemum morifolium

Glycine max

Soil

Vigna sinensis

Solanum tuberosum

Beta vulgaris var.

saccharifera

Brassica oleracea

Beta vulgaris var.

saccharifera

Raphanus sativus

(daikon group)

Soil

Dahlia spp.

Raphanus sativus

Arctium lappa

Solanum tuberosum

Glycine max

Phaseolus radiatus

var. aurea

Phaseolus vulgaris

Soil

Solanum tuberosum

Triticum aestivum

Convallaria keiskei

$6 \cdot 2$

$2 \cdot 7$

$2 \cdot 7$

$2 \cdot 7$

$2 \cdot 7$

$2 \cdot 7$

$2 \cdot 7$

$+$

$2 \cdot 7$
$+\quad 1$

\begin{tabular}{l}
+2.7 \\
\hline
\end{tabular}

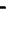

$-$

$-$

-

-

$-$

$+$

Soil

Orchis aristata

$2 \cdot 7$

$2 \cdot 7$

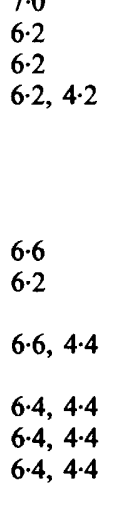

$6 \cdot 6,4 \cdot 4$

$6 \cdot 4,4 \cdot 4$

$6 \cdot 4,4 \cdot 4$

$6 \cdot 4,4 \cdot 4$

$6 \cdot 2$

$6 \cdot 2,4 \cdot 2$

$4 \cdot 4$
$4 \cdot 4$
$4 \cdot 4$
$4 \cdot 4$



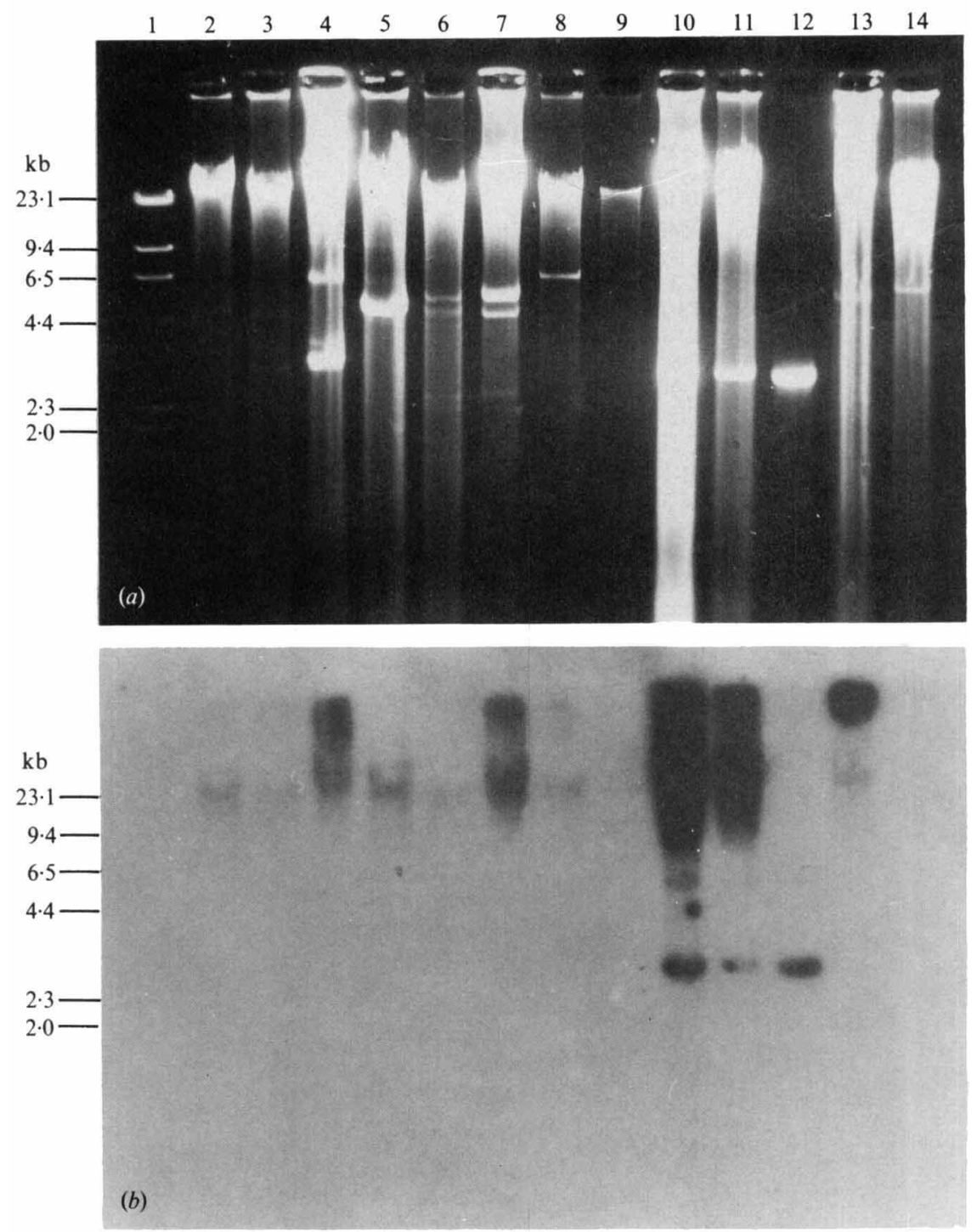

Fig. 1. Detection of plDNAs and Southern hybridization analysis of total DNAs from isolates of different AGs and ISGs. (a) Total DNA from different $R$. solani isolates was separated by electrophoresis and stained with ethidium bromide. (b) Total DNA from the gel in (a) was blotted onto nitrocellulose and hybridized to the entire pIDNA of isolate RI-64 (AG-4) labelled with ${ }^{32} \mathrm{P}$. Lane 1, $\lambda$ DNA digested with HindIII; 2, isolate C-527; 3, C-94; 4, C-616; 5, H-16; 6, BV-6; 7, SH-17-24-1 ; 8, P-7-1, 9, P-5; 10, GM-7; 11, GM-11; 12, RI-64; 13, B-52; 14, HI-5-16.

gradient centrifugation $[7 \mathrm{~g} \mathrm{CsCl}$ and $0.4 \mathrm{ml}$ ethidium bromide $\left(10 \mathrm{mg} \mathrm{ml}^{-1}\right)$ ]. The samples were centrifuged at $95000 \mathrm{~g}$ for $48 \mathrm{~h}$. The bands removed from the gradients were extracted four times with butanol, precipitated with ethanol, and dissolved in TE buffer. A portion of the DNA sample thus obtained was subjected to agarose gel electrophoresis in $0.7 \%$ agarose. The plDNA band(s) was (were) excised and electroeluted. All isolates were independently analysed three times by gel electrophoresis for the presence of pIDNA.

Electron microscopy. A DNA-protein monolayer for electron microscopy was prepared by the formamide and cytochrome $c$ technique as described by Kleinschmidt (1968). Double-stranded pBR322 $(4361 \mathrm{~kb})$ served as an internal length standard. Specimens were observed in a JEM100B type electron microscope.

Southern transfer and hybridization conditions. Total cellular DNAs were fractionated by electrophoresis in a $0.7 \%$ agarose gel, and transferred to nitrocellulose filters. Each pIDNA isolated from the representative isolates of AG-1 to AG- 6 was labelled with $\left[\alpha^{-32} \mathrm{P}\right] \mathrm{dCTP}$ by nick-translation and the radioactively labelled product was hybridized for $24 \mathrm{~h}$ at $42{ }^{\circ} \mathrm{C}$ to DNA in nitrocellulose filters in $50 \%$ (v/v) formamide, $6 \times \mathrm{SSC}, 100 \mu \mathrm{g}$ denatured salmon sperm $\mathrm{DNA} \mathrm{ml}{ }^{-1}$, $5 \times$ Denhardt's solution and $0.5 \%(\mathrm{w} / \mathrm{v})$ SDS $(1 \times$ SSC is $0.15 \mathrm{M}-\mathrm{NaCl}$, $0.015 \mathrm{M}$-sodium citrate $\mathrm{pH} 7.0 ; 1 \times$ Denhardt's solution is $0.02 \%$ Ficoll, $0.02 \%$ bovine serum albumin, $0.02 \%$ polyvinylpyrrolidone). Hybridization patterns were visualized by autoradiography. All these procedures were carried out as described by Maniatis et al. (1982).

\section{Results}

Detection of plDNA by agarose gel electrophoresis

Total DNA was extracted from 114 field isolates of $R$. 
solani (15 isolates of AG-1, 6 isolates of AG-2-1, 14 isolates of AG-2-2 (IIIB), 13 isolates of AG-2-2 (IV), 17 isolates of AG-3, 18 isolates of AG-4, 16 isolates of AG-5, and 15 isolates of AG-6) (Table 1), and purified by $\mathrm{CsCl}$ density-gradient centrifugation. These DNA samples were subjected to agarose gel electrophoresis. The pIDNA was separated as one, two or three bands stained with ethidium bromide as illustrated in Fig. 1 (a). plDNA bands were observed in 48 isolates (Table 1), which were distributed among the nine Japanese AGs and ISGs as follows: 0 in AG-1 (IA), 1 in AG-1 (IB), 0 in AG-2-1, 11 in AG-2-2 (IIIB), 10 in AG-2-2 (IV), 10 in AG-3, 8 in AG-4, 4 in AG-5, and 4 in AG-6. All isolates of AG-1 (IA) and AG-2-1 contained no detectable pIDNA.

The sizes of the plDNAs detected in the $R$. solani isolates of different AGs varied from $2.2 \mathrm{~kb}$ to $7.0 \mathrm{~kb}$ (Table 1). The pIDNAs found in the eight isolates of AG4 and the four isolates of AG-5 each had the same size, $2.7 \mathrm{~kb}$ and $3.2 \mathrm{~kb}$, respectively (Table 1 ). The sizes of the plDNAs found in AG-2, AG-3 and AG-6 varied widely (Table 1). The same or similar sizes of pIDNAs were distributed in different AGs.

\section{Structure of plDNAs}

The plDNAs of representative isolates from eight AGs and ISGs were separated from agarose gel and subjected to electron microscopy. All the plDNAs examined consisted of linear DNA molecules, and no circular molecules, as observed for marker pBR322, were detected (Fig. 2). The sizes of the DNAs estimated by measuring the lengths of linear pIDNA molecules under the electron microscope were in close agreement with those estimated on the basis of mobility on agarose gel.

Sequence homology among plDNAs found in various $R$. solani isolates

plDNAs of different sizes were found in the same or different isolates of $R$. solani. To determine whether these plDNAs had sequence homology, a Southern hybridization analysis was done. The entire lengths of pIDNAs obtained from representative isolates of eight AGs and ISGs were nick-translated and used as hybridization probes. Examples of the resulting autoradiographs are shown in Fig. 1(b). Considerable sequence homology was observed among plDNAs obtained from isolates within the same AG and ISG, but no sequence homology was found among pIDNAs obtained from isolates of different AGs and ISGs (Table 2).

In most isolates of AG-2-2 examined, one of two plDNAs obtained from the same isolate hybridized with
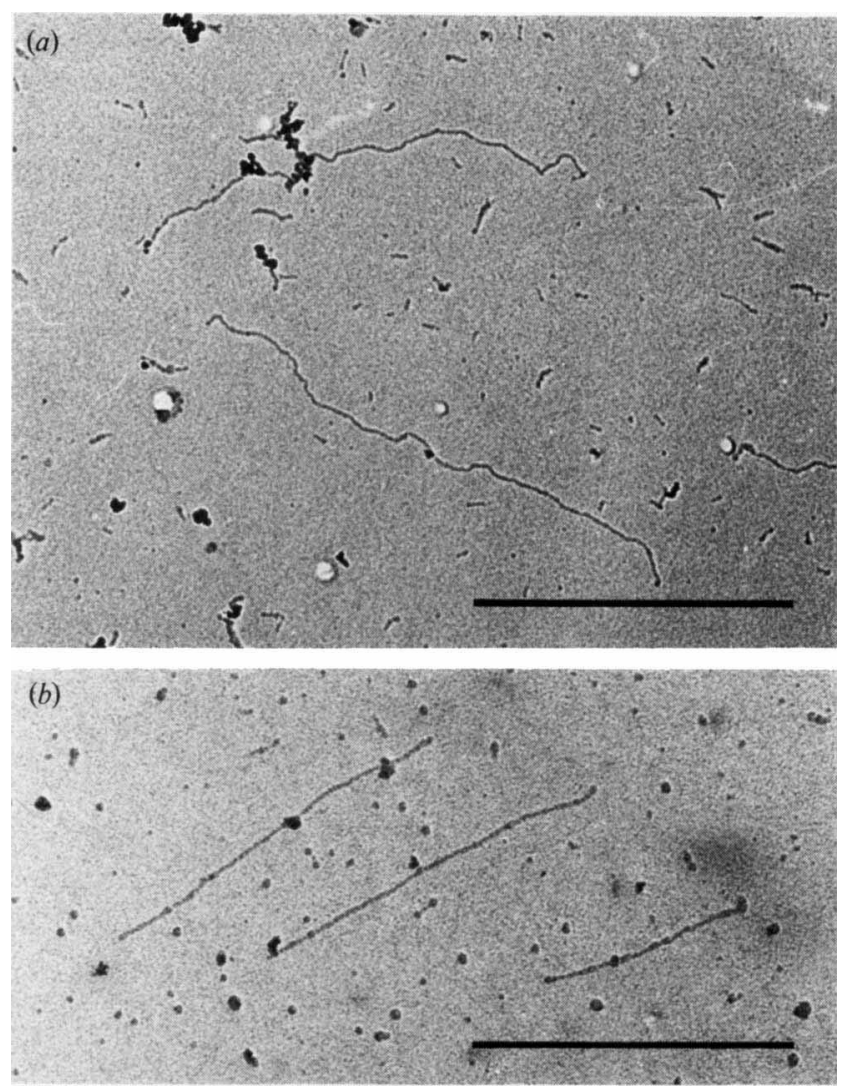

Fig. 2. Electron micrographs of plDNA molecules from two isolates of $R$. solani by the formamide and cytochrome $c$ technique. (a) plDNA molecules from isolate P-7-1 (AG-3); (b) pIDNA molecules from isolate ST-8 (AG-5). Bars, $1 \mu \mathrm{m}$.

the probe, but in some isolates of AG-2-2 both pIDNAs obtained from the same isolate hybridized with the same probe (Table 2). Within AG-2-2, the plDNAs of AG-2-2 (IIIB) isolates hybridized with the probe of AG-2-2 (IIIB) (isolate C-94), but not with that of AG-2-2 (IV) (isolate $\mathrm{H}-16$ ). In contrast, the plDNAs of AG-2-2 (IV) isolates hybridized with the probe of AG-2-2 (IV), but not with that of AG-2-2 (IIIB) (Table 2). The pIDNA of one isolate of AG-2-2 (isolate BV-6) hybridized with both probes.

\section{Discussion}

Analysis of total DNA from $R$. solani field isolates of different AGs and ISGs showed that about half of the isolates (48 out of 114 ) contained pIDNA. The percentage of isolates carrying plDNA ( $42 \%)$ is much higher than that reported previously (Hashiba et al., 1984). The plDNAs carried by the 48 isolates ranged from $2 \cdot 2$ to $7.0 \mathrm{~kb}$ in size. In the case of AG-4 and AG-5, the plDNAs of each isolate in the respective AG had the same size, $2.7 \mathrm{~kb}$ and $3.2 \mathrm{~kb}$, respectively. pIDNA was 
Table 2. Southern hybridization analysis of plDNA from $R$. solani AG-1 to -6 isolates probed with plDNA from a representative isolate of each $A G$ or $I S G$

Key: $\mathbb{P}$, the entire length of a plDNA obtained from the representative isolates of one AG or ISG was used as the hybridization probe; $\boxplus$, considerable sequence homology was observed; -, no sequence homology was observed.

\begin{tabular}{|c|c|c|c|c|c|c|c|c|c|c|}
\hline \multirow[b]{2}{*}{ AG } & \multirow[b]{2}{*}{$\begin{array}{l}\text { Pathological } \\
\text { type }\end{array}$} & \multirow[b]{2}{*}{ Isolate } & \multirow[b]{2}{*}{$\begin{array}{c}\text { Size of } \\
\text { plDNA } \\
\text { (kb) }\end{array}$} & \multicolumn{7}{|c|}{ Source of probe: } \\
\hline & & & & $\begin{array}{c}\text { C-527 } \\
\text { (AG-1) }\end{array}$ & $\begin{array}{c}\text { C-94 } \\
\text { (AG-2-2 } \\
\text { IIIB) }\end{array}$ & $\begin{array}{c}\text { H-16 } \\
\text { (AG-2-2 } \\
\text { IV) }\end{array}$ & $\begin{array}{l}\text { P-7-1 } \\
\text { (AG-3) }\end{array}$ & $\begin{array}{l}\text { RI-64 } \\
(A G-4)\end{array}$ & $\begin{array}{c}\text { ST-8 } \\
\text { (AG-5) }\end{array}$ & $\begin{array}{l}\text { HI-5-16 } \\
\text { (AG-6) }\end{array}$ \\
\hline 1 & $\begin{array}{l}\text { Web-blight } \\
\text { type (IB) }\end{array}$ & C-527 & $5 \cdot 5$ & $\mathrm{P}$ & - & - & - & - & - & - \\
\hline $2-2$ & $\begin{array}{l}\text { Rush type } \\
\text { (IIIB) }\end{array}$ & $\begin{array}{l}\text { C-6 } \\
C-94 \\
C-125\end{array}$ & $\begin{array}{l}5 \cdot 2 \\
3 \cdot 2 \\
4 \cdot 0 \\
3 \cdot 0 \\
4 \cdot 3 \\
2 \cdot 9 \\
4 \cdot 2 \\
2 \cdot 9 \\
4 \cdot 7 \\
2 \cdot 9\end{array}$ & $\begin{array}{l}- \\
- \\
- \\
- \\
- \\
- \\
- \\
- \\
-\end{array}$ & $\begin{array}{l}\bar{\square} \\
\overline{\mathbf{D}} \\
\bar{\oplus} \\
\bar{\oplus} \\
\bar{\square}\end{array}$ & $\begin{array}{l}- \\
- \\
- \\
- \\
- \\
- \\
- \\
- \\
- \\
-\end{array}$ & $\begin{array}{l}- \\
- \\
- \\
- \\
- \\
- \\
- \\
- \\
-\end{array}$ & $\begin{array}{l}- \\
- \\
- \\
- \\
- \\
- \\
- \\
- \\
-\end{array}$ & $\begin{array}{l}- \\
- \\
- \\
- \\
- \\
- \\
- \\
-\end{array}$ & $\begin{array}{l}- \\
- \\
- \\
- \\
- \\
- \\
- \\
- \\
-\end{array}$ \\
\hline $2-2$ & $\begin{array}{l}\text { Root rot } \\
\text { type (IV) }\end{array}$ & $\begin{array}{l}\text { A-14-1 } \\
\text { BV-6 } \\
\text { C-616 } \\
\text { C-623 } \\
\text { H-16 } \\
\text { SH-17-24-1 }\end{array}$ & $\begin{array}{l}4.7 \\
4.0 \\
2.4 \\
3.0 \\
5.5 \\
2.9 \\
5 \cdot 4 \\
4 \cdot 7 \\
5.0 \\
4 \cdot 2\end{array}$ & $\begin{array}{l}- \\
- \\
- \\
- \\
- \\
- \\
- \\
- \\
-\end{array}$ & $\begin{array}{l}\bar{\oplus} \\
\\
- \\
- \\
- \\
- \\
- \\
-\end{array}$ & 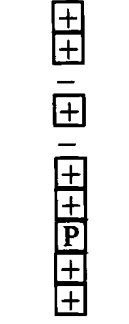 & $\begin{array}{l}- \\
- \\
- \\
- \\
- \\
- \\
- \\
- \\
- \\
-\end{array}$ & $\begin{array}{l}- \\
- \\
- \\
- \\
- \\
- \\
- \\
- \\
- \\
-\end{array}$ & $\begin{array}{l}- \\
- \\
- \\
- \\
- \\
- \\
- \\
- \\
- \\
-\end{array}$ & $\begin{array}{l}- \\
- \\
- \\
- \\
- \\
- \\
- \\
- \\
- \\
-\end{array}$ \\
\hline 3 & $\begin{array}{l}\text { Potato type } \\
\text { (IV) }\end{array}$ & $\begin{array}{l}\text { P-5 } \\
\text { P-7-1 } \\
\text { ST-3 }\end{array}$ & $\begin{array}{l}6 \cdot 2 \\
6 \cdot 2 \\
6 \cdot 2\end{array}$ & $\begin{array}{l}- \\
-\end{array}$ & $\begin{array}{l}- \\
- \\
-\end{array}$ & $\begin{array}{l}- \\
- \\
-\end{array}$ & \begin{tabular}{|l|} 
\\
$\mathrm{P}$ \\
\end{tabular} & $\begin{array}{l}- \\
- \\
-\end{array}$ & $\begin{array}{l}- \\
- \\
-\end{array}$ & $\begin{array}{l}- \\
- \\
-\end{array}$ \\
\hline 4 & $\begin{array}{l}\text { Praticola } \\
\text { type (IIIA) }\end{array}$ & $\begin{array}{l}\text { GM-7 } \\
\text { GM-11 } \\
\text { RI-64 }\end{array}$ & $\begin{array}{l}2 \cdot 7 \\
2 \cdot 7 \\
2 \cdot 7\end{array}$ & $\begin{array}{l}- \\
- \\
-\end{array}$ & $\begin{array}{l}- \\
- \\
-\end{array}$ & $\begin{array}{l}- \\
-\end{array}$ & $\begin{array}{l}- \\
-\end{array}$ & \begin{tabular}{|l|} 
\pm \\
+ \\
$\mathrm{P}$ \\
\end{tabular} & $\begin{array}{l}- \\
- \\
-\end{array}$ & $\begin{array}{l}- \\
- \\
-\end{array}$ \\
\hline 5 & & $\begin{array}{l}\text { ST-2-1 } \\
\text { ST-8 } \\
\text { W-3 } \\
501\end{array}$ & $\begin{array}{l}3 \cdot 2 \\
3 \cdot 2 \\
3 \cdot 2 \\
3 \cdot 2\end{array}$ & $\begin{array}{l}- \\
- \\
- \\
-\end{array}$ & $\begin{array}{l}- \\
- \\
- \\
-\end{array}$ & $\begin{array}{l}- \\
- \\
-\end{array}$ & $\begin{array}{l}- \\
- \\
-\end{array}$ & $\begin{array}{l}- \\
- \\
-\end{array}$ & \begin{tabular}{|l|}
$\mathbf{H}$ \\
$\mathbf{P}$ \\
+ \\
$t$ \\
\end{tabular} & $\begin{array}{l}- \\
- \\
- \\
-\end{array}$ \\
\hline 6 & & HI-5-16 & $5 \cdot 2$ & - & - & - & - & - & - & $\mathrm{P}$ \\
\hline
\end{tabular}

not found in the six isolates of AG-2-1 examined, and pIDNA was found in only one of the 15 isolates of AG-1. The frequency of distribution of isolates carrying plDNAs may be different depending on the AGs and ISGs or host plants.

Each isolate of AG-2-2 and AG-3 that carried pIDNA contained one, two or three plDNAs of different sizes identified by gel electrophoresis, whereas the pIDNAcarrying isolates of AG-1, AG-4, AG-5 and AG-6 contained only one plDNA. Originally we found the pRS64 plasmid as a single band on agarose gel (Hashiba et al., 1984; Hashiba, 1987a, b), but subsequent restriction mapping showed that pRS64 actually consisted of three species of plasmids, pRS64-1, -2 and -3
(Miyashita et al., 1990). This suggests that different species of plasmids may well be involved in bands of the same size observed in the present study.

Electron micrographs of purified plDNAs revealed that they were linear molecules. Most linear plasmid DNAs, including the linear plasmids found in phytopathogenic fungi, have terminal proteins covalently attached to the $5^{\prime}$ termini. These proteins are thought to work as primers. The three linear plasmid DNAs, pRS64-1, -2 and -3, obtained from the isolate RI-64 (AG4) have hairpin loops at both termini (Miyashita et al., 1990). Southern blotting analysis of total DNA obtained from RI-64 showed the presence of dimeric forms of pRS64 DNA (Miyashita et al., 1990). We suggested that 
these dimeric forms of pRS64 may be involved in the replication system of pRS64 DNA, and proposed a possible model for replication of pRS64 plasmids (Miyashita et al., 1990). More work is required to determine whether all pIDNAs of $R$. solani have the same hairpin loop structure at both termini.

Linear mitochondrial plasmids have been detected in a wide variety of phytopathogenic fungi (Tudzynski et al., 1986; Garber et al., 1986). In order to determine the location of pIDNAs in AG-4 of $R$. solani, mitochondria were isolated by differential centrifugation. After DNAase treatment of mitochondria the plDNAs were still found, indicating their mitochondrial location (unpublished results). However, these experiments do not rule out the possibility that the pIDNA exist extramitochondrially in the cytoplasm as well as within mitochondria.

Southern hybridization analysis of various $R$. solani isolates showed that the plDNAs have considerable sequence homology among isolates of the same $\mathrm{AG}$ and ISG, but not among those of different AGs and ISGs. This suggests that the distribution of plDNAs correlates with the distinct host range of AG and ISG in $R$. solani, and may be used for the classification of this fungus. The relationship between the pIDNAs and AGs or ISGs is in agreement with the results of DNA base sequence homology (Kuninaga \& Yokosawa, 1985), serological comparisons (Adams \& Butler, 1979), DNA base comparison (Kuninaga \& Yokosawa, 1980), ecological and morphological characteristics (Ogoshi, 1976), and electrophoresis of isoenzymes (Matsuyama et al., 1978) and soluble proteins (Reynolds et al., 1983). Since these plDNAs are host-specific, they may carry genes that determine host specialization. We wish to determine whether these plDNAs contain open reading frames that are transcribed and translated. This will require a transformation system for $R$. solani to be established. The relationship between the plDNAs and the nature of AGs may also be indicated by using plasmid-cured strains of $R$. solani. We hope to resolve the question by manipulating plasmid-free, plasmid-containing and cured strains by protoplast fusion.

The authors wish to sincerely thank $\operatorname{Dr} \mathrm{T}$. Ishikawa, Teikyo University, Japan, for helpful suggestions and critical reading of the manuscript, and Dr. Y. Ehara for kind help. They thank Drs A. Ogoshi, University of Hokkaido at Sapporo, M. Hyakumachi, Gifu University at Gifu, and Y. Homma, Hokkaido National Agricultural Experiment Station at Sapporo, for providing $R$. solani isolates. This work was supported by grants from the Ministry of Education, Science and Culture of Japan, and the Ministry of Agriculture, Forestry and Fisheries of Japan (BMP90-1II-2-4).

\section{References}

Adams, G. C., JR \& Butler, E. E. (1979). Serological relationships among anastomosis groups of Rhizoctonia solani. Phytopathology 69, 629-633.

Garber, R. C., Turgeon, B. G. \& Yoder, O. C. (1984). A mitochondrial plasmid from the plant pathogenic fungus Cochliobolus heterostrophus. Molecular and General Genetics 196, 301-310.

GARBER, R. C., LIN, J. J. \& Yoder, O. C. (1986). Mitochondrial plasmids in Cochliobolus heterostrophus. In Extrachromosomal Elements in Lower Eukaryotes (Basic Life Sciences, vol. 40), pp. 105-118. Edited by R. B. Wichner, A. Hinnebusch, A. M. Lambowitz, J. C. Gunsalus \& A. Hollaender. New York \& London: Plenum Press.

Giasson, L. \& LALONDE, M. (1987). Analysis of a linear plasmid isolated from the pathogenic fungus Ceratocystis fimbriata Ell. \& Halst. Current Genetics 11, 331-334.

HashiBA, T. (1987a). An improved system for biological control of damping-off by using plasmids in fungi. In Innovative Approaches to Plant Disease Control, pp. 337-351. Edited by I. Chet. New York: John Wiley.

HashiBa, T. $(1987 b)$. Plasmids responsible for pathogenicity and morphology in Rhizoctonia solani. In Molecular Determinants of Plant Diseases, pp. 157-168. Edited by S. Nishimura, C. P. Vance \& N. Doke. Tokyo \& Berlin: Japan Scientific Societies \& Springer-Verlag Press.

HaSHibA, T. (1988). Role of linear DNA plasmids in plant pathogenic fungi. 5th International Congress of Plant Pathology, p. 12 (abstract).

Hashiba, T., Homma, Y., Hyakumachi, M. \& Matsuda, I. (1984). Isolation and characterization of a DNA plasmid in the fungus Rhizoctonia solani. Journal of General Microbiology 130, 20672070.

HIRT, B. (1967). Selective extraction of polyoma DNA from infected mouse cell cultures. Journal of Molecular Biology 26, 365-369.

Honeyman, A. L. \& CURRIER, T. C. (1986). Isolation and characterization of linear DNA elements from the mitochondria of Gaeumannomyces graminis. Applied and Environmental Microbiology 52, 924929.

KIM, W. K., MCNabB, S. A. \& KLASSEN, G. R. (1988). A linear plasmid in Tilletia controversa, a fungal pathogen of wheat. Canadian Journal of Botany 66, 1098-1100.

KistleR, H. C. \& LeONG, S. A. (1986). Linear plasmidlike DNA in the plant pathogenic fungus Fusarium oxysporum f. sp. conglutinans. Journal of Bacteriology 167, 587-593.

Kistler, H. C., Bosland, P. W., BenNy, V., Leong, S. A. \& WilliaMs, P. H. (1987). Relatedness of strains of Fusarium oxysporum from crucifers measured by examination of mitochondrial and ribosomal DNA. Phytopathology 77, 1289-1293.

KLeINSCHMIDT, A. (1968). Monolayer techniques in electron microscopy of nucleic acid molecules. Methods in Enzymology 12, 361-377.

Kuninaga, S. \& Yokosawa, R. (1980). A comparison of DNA base compositions among anastomosis groups in Rhizoctonia solani Kühn. Annals of the Phytopathological Society of Japan 46, 150-158.

KuninaGa, S. \& YoKosaWA, R. (1985). DNA base sequence homology in Rhizoctonia solani Kühn. VI. Genetic relatedness among seven anastomosis groups. Annals of the Phytopathological Society of Japan 51, 127-132.

Maniatis, T., Fritsch, E. F. \& SAMBrooK, J. (1982). Molecular Cloning. A Laboratory Manual. Cold Spring Harbor NY: Cold Spring Harbor Laboratory.

Matsuyama, N., Moromizato, Z., Ogoshi, A. \& Wakimoto, S. (1978). Grouping Rhizoctonia solani Kühn with non-specific esterase zymogram. Annals of the Phytopathological Society of Japan 44, 652658.

MiYasaka, A., Hashiba, T. \& EhaRA, Y. (1988). Detection and properties of plasmidlike DNA in isolates from 6 anastomosis groups of Rhizoctonia solani. 5th International Congress of Plant Pathology p. 197 (abstract).

Miyashita, S., Hirochika, H., Ikeda, J.-E. \& Hashiba, T. (1990). Linear plasmid DNAs of the plant pathogenic fungus Rhizoctonia solani with unique terminal structures. Molecular and General Genetics 220, 165-171. 
OGoshI, A. (1976). Studies on the grouping of Rhizoctonia solani Kühn with hyphal anastomosis and on the perfect stages of groups. Bulletin of the National Institute of Agricultural Sciences, Series C 30, 1-63.

REYNOLDS, M., WeINHOLD, A. R. \& MoRRIS, T. J. (1983). Comparison of anastomosis groups of Rhizoctonia solani by polyacrylamide gel electrophoresis of soluble proteins. Phytopathology 73, 903-906.

RUBIDGE, T. (1986). Survey of Fusarium species for plasmid-like DNA and some evidence for its occurrence in a strain of $F$. merismoides. Transactions of the British Mycological Society 87, 463-466.

SAMAC, D. A. \& Leong, S. A. (1988). Two linear plasmids in mitochondria of Fusarium solani f. sp. cucurbitae. Plasmid 19, 57-67.
TUDZYNSKI, P. \& EsSER, K. (1986). Extrachromosomal genetics of Claviceps purpurea. II. Plasmids in various wild strains and integrated plasmid sequences in mitochondrial genomic DNA. Current Genetics 10, 463-467.

Tudzynski, P., Rogmann, P. \& Neuhaus, H. (1986). Extrakaryotic inheritance: mitochondrial genetics. Progress in Botany 48, 249259.

Watanabe, B. \& Matsuda, A. (1966). Studies on the grouping of Rhizoctonia solani Kühn pathogenic to upland crops. Appointed Experiment (Plant Diseases and Insect Pests) Agriculture, Forestry and Fishery Research Council, Japan 7, 1-131. 